\title{
Serum IL-35 is decreased in overweight patients with rheumatoid arthritis: its correlation with Th1/Th2/Th17-related cytokines
}

Yuxuan $\mathrm{Li}^{1}$, Yang Jie ${ }^{2}$, Xiaofei Wang ${ }^{1 *}$ and Jing $\mathrm{Lu}^{2^{*}}$

\begin{abstract}
Background: Obesity is correlated with worse drug responses and high disease activity in patients with rheumatoid arthritis (RA). Interleukin (IL)-35 is a novel anti-inflammatory cytokine that mainly produced by regulatory $T$ (Treg). This study was performed to analyze whether IL-35 was correlated with obesity in RA and investigate the correlation between other Th1/Th2/Th17-related cytokines and obesity in RA.

Results: The serum IL-35 level was analyzed in RA $(n=81)$ and healthy donors $(n=53)$ by ELISA assay, and was compared between three groups (body mass index (BMI) $<18.5, \geq 18.5$ to $25,>25$ ). Serum cytokines including IL-2, IL-4, IL-10, IL-17, INF- $\gamma$, TNF-a levels were measured using Flowcytometry assay. Clinical information was extracted from medical records. Serum IL-35 level in overweight patients were significantly decreased than those in lean patients. Furthermore, Th1/Th2/Th17-related cytokines from overweight patients with RA showed the characteristic immunological features. Serum IL-6, IL-17 and TNF-a levels were positively correlated with BMI. However, serum IL-2, IL4, IL-10 and IFN- $\gamma$ concentrations were not correlated with BMI.

Conclusions: Quantitative changes in serum IL-35 level were characteristic in overweight patients with RA. These findings indicate that IL-35 plays an important role in the development of RA and may prove to be a potential biomarker of active RA.
\end{abstract}

Keywords: Interlukin-35, Th1/Th2/Th17 cytokines, Rheumatoid arthritis, Obesity

\section{Background}

Rheumatoid arthritis (RA) is characterized as a chronic inflammatory autoimmune disease which caused by multiple genetic and environmental factors. Some environmental factors including smoking and obesity has been demonstrated to significantly affect the prognosis of patients with RA.

\footnotetext{
*Correspondence: wangx@@sj-hospital.org; lujingtan@163.com

'Department of Rheumatology and Immunology, Shengjing Hospital of

China Medical University, No. 36 San Hao Street, Heping District, Shenyang 110004, PR China

${ }^{2}$ Department of Rheumatology and Immunology, The First Affiliated Hospital of China Medical University, 155 Nanjing North Street, Heping District, Shenyang 110001, PR China
}

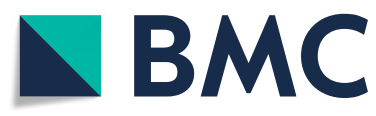

(C) The Author(s). 2021 Open Access This article is licensed under a Creative Commons Attribution 4.0 International License, which permits use, sharing, adaptation, distribution and reproduction in any medium or format, as long as you give appropriate credit to the original author(s) and the source, provide a link to the Creative Commons licence, and indicate if changes were made. The images or other third party material in this article are included in the article's Creative Commons licence, unless indicated otherwise in a credit line to the material. If material is not included in the article's Creative Commons licence and your intended use is not permitted by statutory regulation or exceeds the permitted use, you will need to obtain permission directly from the copyright holder. To view a copy of this licence, visit http://creativecommons.org/licenses/by/4.0/ The Creative Commons Public Domain Dedication waiver (http://creativecommons.org/publicdomain/zero/1.0/) applies to the data made available in this article, unless otherwise stated in a credit line to the data.
Obesity has also been confirmed as one of the most important environmental risk factors for RA. It is reported that obesity could prolong the disease course and give rise to poor responses to biological therapy [1, 2]. High disease activity is also observed in obese patients with early RA [3]. RA patients who have a high body mass index (BMI) were confirmed to have worse outcomes regarding to disease activity and comorbidities [4]. Previous studies have showed that obesity and inflammation are tightly linked, which contributes to the risk and severity of RA. The linkage between obesity and RA is being investigated. Multiple immune cells 
orchestrate and interplay in the development of RA. The underlying hypothesis is that white adipose tissue which secretes multiple pro-inflammatory and antiinflammatory cytokines such as interleukin (IL)-6, tumor necrosis factor (TNF)- $\alpha$ could modulate immune response and inflammation, and store energy under conditions of caloric surplus [5-7].

IL-35, a novel cytokine, is a member of IL-12 family. It consists of the IL-12p35 subunit and IL-27subunit EpsteinBarr virus-induced 3 (EBI3, [8]). IL-35 is reported as an immunosuppressive cytokine and is mainly produced by regulatory $\mathrm{T}$ cells (Tregs), regulates immunological functions through inhibiting the inflammatory response [9]. IL-35 could induce the production of a subset of Tregs and Bregs, regulate their immuno-suppressive function and suppress the differentiation of Th17 cells. It could also upregulate the expression of osteoprotegerin and inhibit the expression of RANKL, thus inhibiting the progression of bone loss in collagen-induced arthritis (CIA) mice model. Furthermore, IL-35 inhibited proliferation and promoted apoptosis of FLS in CIA mice. Yokota et al. found that IL-35 significantly reduced the production of IL-4, IL-17 and TNF- $\alpha$, and significantly increased the production of IL-2 and IL-10 [10]. IL-35 secretion is influenced by immune states. Studies demonstrated that injection of recombinant IL-35 can be used to protect against autoimmune diabetes [11]. Besides IL-35, various cytokines, both proinflammatory and antiinflammatory, also have been analyzed in patients with RA, and the balance between the activities of these opposite cytokines lead to disease severity [12]. The imbalance between pro-inflammatory and anti-inflammatory cytokines responses favors the activation of autoimmunity and thereby joint destruction [13]. Considering the relationship between cytokines and RA symptoms of patients, multiple Th1/Th2/ Th17-related cytokines were detected as the crucial biomarkers for patients with RA [14]. Modulation of the imbalance of pro-inflammatory and anti-inflammatory responses, particularly for Th1 and Th2 as well as their cytokine responses is a therapeutic strategy for retarding the pathogenic process of RA $[15,16]$.

In the previous study, the serum IL-35 level was compared between patients with RA and health controls, and some differences were identified, such as an increase of serum IL-35 level in patients with RA. In the current study, we analyzed this information in view of their relationship with BMI. Furthermore, Th1/Th2/Th17-related cytokines were also analyzed in order to explore the immunological features in overweight patients with RA.

\section{Results}

\section{Characteristics of the study population}

Patients were matched for age, gender, and BMI. Meanwhile, patients were categorized into three groups according to BMI $(<18.5, \geq 18.5$ to $25,>25)$, as previously defined. A summary of RA patient profiles is listed in Table 1.

\section{Correlation between serum IL-35 levels and obesity}

In current study, BMI and lipid profile including total cholesterol, triglycerides, LDL-C, HDL-C, apoplipoprotein A1 and apoplipoprotein $\mathrm{B}$ were used to explore the relationship between IL-35 and obesity in RA. The serum IL-35 level in total RA patients, three subgroups and healthy controls were presented in Table 2.We found that the serum IL-35 level in total patients with RA was significantly elevated compared to that in healthy controls (median (IQR), $11.6(5.1-16.8) \mathrm{pg} / \mathrm{ml}$ vs $1.5(0.8-3.2) \mathrm{pg} / \mathrm{ml})(\mathrm{p}<0.0001)$. Furthermore, serum IL-35 level was negatively correlated with BMI in patients with RA $(r=-0.26, p=0.02)$. In addition, serum IL-35 level in overweight patients were significantly decreased than those in lean patients $(p=0.0229)$. However, IL-35 were not correlated with serum levels of lipids ( $p>0.05)$ (Fig. 1).

\section{Correlations between Th1/Th2/Th17-related cytokines and BMI}

Serum pro-inflammatory and anti-inflammatory cytokines were measured in patients with RA and were analyzed for correlation with BMI. Serum IL-6, IL-17A and TNF- $\alpha$ levels were positively correlated with BMI $(r=$ $0.2292, p=0.0067 ; r=0.4761, p<0.0001 ; r=0.4500, p<$ 0.0001 , respectively). However, serum IL-2, IL-4, IL-10 and IFN- $\gamma$ concentrations were not correlated with BMI $(r=-0.1395, p=0.0835 ; \quad r=0.1326, p=0.2381 ; \quad r=-$ $0.0571, p=0.6126 ; r=0.0699, p=0.5353$, respectively) (Table 3). The regression analysis to highlight correlations between BMI and DAS28, Th1/Th2/Th17 related cytokines was shown in the (Supplemental Fig. 1).

\section{Cytokines expression in overweight patients with RA}

The typical two-dimensional scatter diagrams of the frequency of Th1/Th2/Th17-Related Cytokines in patients with RA were shown in (Supplementary Fig. 2). In our study, serum levels of IL-6, IL-17 and TNF- $\alpha$ were found to be significantly higher $(p=0.0059, p=0.00192, p=$ 0.0237 , respectively) in the overweight group with RA $(\mathrm{BMI}>25)$ than in lean controls $(\mathrm{BMI}<18.5)$ (Fig. 2C, E, G). Moreover, no significant differences were observed in serum levels of IL-2, IL-4, IL-10 and IFN- $\gamma$ between the 3 groups of patients with RA (Fig. 2A, B, D, F).

\section{Discussion}

Obesity is a common condition in China and its global rise has contributed to subsequent morbidities. The levels of serum fibrinogen and other acute phase reactants, such as TNF- $\alpha$, IL-6, and CRP were demonstrated to be increased in obesity [17]. This situation also leads to autoimmune diseases such as RA. Previous study confirmed that obesity involves in the progression and 
Table 1 Clinical parameters of RA and HCs

\begin{tabular}{|c|c|c|c|c|c|c|c|}
\hline \multirow[t]{2}{*}{ Characteristics } & \multirow{2}{*}{$\begin{array}{l}\text { RA } \\
(n=81)\end{array}$} & \multirow{2}{*}{$\begin{array}{l}\mathrm{HCs} \\
(n=53)\end{array}$} & \multirow{2}{*}{$\begin{array}{l}P \\
\text { value }\end{array}$} & \multicolumn{3}{|c|}{ RA patients $(n=81)$} & \multirow{2}{*}{$\begin{array}{l}P \\
\text { value }\end{array}$} \\
\hline & & & & $\begin{array}{l}\mathrm{BMI}<18.5 \\
(n=17)\end{array}$ & $\begin{array}{l}18.5 \leq \mathrm{BMI} \leq 25 \\
(n=47)\end{array}$ & $\begin{array}{l}\mathrm{BMI}>25 \\
(n=17)\end{array}$ & \\
\hline \multicolumn{8}{|l|}{ Demographics } \\
\hline Age, mean $\pm S E$, years & $50.0 \pm 1.6$ & $53.3 \pm 2.8$ & 0.67 & $41.6 \pm 3.9$ & $52.5 \pm 2.1$ & $52.1 \pm 2.6$ & 0.64 \\
\hline $\operatorname{Sex}(F / M)$ & $72 / 9$ & $50 / 3$ & 0.88 & $18 / 1$ & $41 / 5$ & $13 / 3$ & 0.54 \\
\hline \multicolumn{8}{|l|}{ Lipid profiles } \\
\hline $\mathrm{TC}$, mean $\pm \mathrm{SE}, \mathrm{mmol} / \mathrm{L}$ & $4.3 \pm 0.1$ & $4.2 \pm 0.3$ & 0.74 & $3.9 \pm 0.2$ & $4.4 \pm 0.1$ & $4.4 \pm 0.3$ & 0.13 \\
\hline $\mathrm{TG}$, mean $\pm \mathrm{SE}, \mathrm{mmol} / \mathrm{L}$ & $1.1 \pm 0.07$ & $0.8 \pm 0.1$ & 0.55 & $0.8 \pm 0.06$ & $1.1 \pm 0.1$ & $1.3 \pm 0.2$ & 0.087 \\
\hline $\mathrm{HDL}-\mathrm{C}$, mean $\pm \mathrm{SE}, \mathrm{mmol} / \mathrm{L}$ & $1.2 \pm 0.04$ & $1.3 \pm 0.02$ & 0.34 & $1.2 \pm 0.08$ & $1.2 \pm 0.07$ & $1.0 \pm 0.07$ & 0.03 \\
\hline $\mathrm{LDL}-\mathrm{C}$, mean $\pm \mathrm{SE}, \mathrm{mmol} / \mathrm{L}$ & $2.6 \pm 0.08$ & $2.5 \pm 0.1$ & 0.48 & $2.3 \pm 0.1$ & $2.6 \pm 0.1$ & $2.9 \pm 0.2$ & 0.080 \\
\hline Apoplipoprotein $\mathrm{A} 1$, mean $\pm \mathrm{SE}, \mathrm{g} / \mathrm{L}$ & $1.3 \pm 0.03$ & $1.3 \pm 0.05$ & 0.93 & $1.3 \pm 0.08$ & $1.3 \pm 0.05$ & $1.2 \pm 0.07$ & 0.82 \\
\hline Apoplipoprotein B, mean $\pm S E, g / L$ & $0.8 \pm 0.02$ & $0.9 \pm 0.01$ & 0.81 & $0.7 \pm 0.04$ & $0.8 \pm 0.03$ & $0.9 \pm 0.07$ & 0.015 \\
\hline \multicolumn{8}{|l|}{ Disease characteristics } \\
\hline $\mathrm{ESR}$, mean $\pm \mathrm{SE}, \mathrm{mm} / \mathrm{h}$ & $56.8 \pm 4.5$ & - & & $56.7 \pm 11.1$ & $54.2 \pm 6.1$ & $63.1 \pm 13.3$ & 0.68 \\
\hline $\mathrm{CRP}$, mean $\pm \mathrm{SE}, \mathrm{mg} / \mathrm{L}$ & $38.2 \pm 5.0$ & - & & $40.4 \pm 11.8$ & $27.0 \pm 4.3$ & $55.8 \pm 19.5$ & 0.77 \\
\hline $\mathrm{TJC}$, mean $\pm \mathrm{SE}$ & $8 \pm 0.1$ & - & & $7 \pm 0.1$ & $9 \pm 0.2$ & $9 \pm 0.1$ & 0.81 \\
\hline $\mathrm{SJC}$, mean $\pm \mathrm{SE}$ & $8 \pm 0.2$ & - & & $7 \pm 0.3$ & $8 \pm 0.2$ & $9 \pm 0.3$ & 0.86 \\
\hline $\mathrm{DAS} 28-\mathrm{ESR}$, mean $\pm \mathrm{SE}$ & $5.9 \pm 0.2$ & - & & $5.5 \pm 0.7$ & $5.8 \pm 0.3$ & $6.0 \pm 0.5$ & 0.09 \\
\hline $\mathrm{RF}$ titers, mean $\pm \mathrm{SE}, \mathrm{IU} / \mathrm{mL}$ & $226.4 \pm 41.5$ & - & & $331.1 \pm 75.2$ & $262.2 \pm 63.2$ & $113.6 \pm 41.38$ & 0.06 \\
\hline $\mathrm{ACPA}$ titers, mean $\pm \mathrm{SE}, \mathrm{U}$ & $281.5 \pm 14.9$ & - & & $279.1 \pm 41.1$ & $306.3 \pm 20.4$ & $256.3 \pm 44.8$ & 0.88 \\
\hline
\end{tabular}

Abbreviations: RA rheumatoid arthritis, HCs healthy controls, BMI body mass index, TC total cholesterol, TG triglyceride, HDL-C high-density lipoprotein cholesterol, LDL-C low-density lipoprotein cholesterol, ESR erythrocyte sedimentation rate; CRP, C-reaction protein; TJC, tender joint count; SJC, swollen joint count; VAS visual analogue scale, DAS28-ESR disease activity score in 28 joints based on erythrocyte sedimentation rate, $R F$ rheumatoid factor, $A C P A$ anti-cyclic citrullinated peptide antibodies, IQR interquartile range, SE standard error

development of RA at different stages [18]. Cytokines are key regulators of inflammation which play an important role in inflammatory diseases via a complicated network of interactions. A better understanding of cytokine expression and related signaling pathways will help promote more effective treatment of chronic inflammatory diseases such as RA. In the current study we explored the correlation between cytokines and obesity by analyzing serum concentrations of multiple cytokines in lean, normal and overweight patients with RA.

The important finding from the current study is that BMI is associated with simultaneous production of serum IL-35 of overweight patients compared to lean patients. Our previous study showed that IL-35 was highly expressed in patients with RA and that serum IL35 expression correlated negatively with the disease activity. This result was opposite to the findings of the Ning's group [19]. This contradicting result could be explained by different sample size, disease duration and medical type in RA patients, which suggesting IL-35 might play different immunoregulatory role in different phases of RA. Previous studies have confirmed that IL35 is preferentially produced by regular $\mathrm{T}$ cells (Tregs) during immunosuppression and can stimulate their activity. Tregs require IL-35 to maximize their regulatory activity and curb $\mathrm{T}$ cell proliferation, which efficaciously refrain the development of inflammation [20]. Furthermore, IL-35 was found as an anti-inflammatory cytokine which could inhibit the differentiation of Th17 cells in murine models of RA [21]. We previously found that serum levels of IL-35 negatively correlated with disease activity in patients with RA [22]. Meanwhile, serum IL35 levels were significantly increased in response to tofacitinib in patients with RA, which suggesting IL-35 play an important role in the immunomodulation of RA [23]. In the state of obesity, the imbalance of Th1, Th2, Th17

Table 2 Serum IL-35 level in RA patients and HCS

\begin{tabular}{|c|c|c|c|c|c|c|}
\hline & \multirow{2}{*}{$\begin{array}{l}\mathrm{RA} \\
(n=81)\end{array}$} & \multirow{2}{*}{$\begin{array}{l}\text { HCs }(n= \\
53)\end{array}$} & \multirow[t]{2}{*}{$P$ value } & \multicolumn{3}{|c|}{ RA patients $(n=81)$} \\
\hline & & & & $\begin{array}{l}\mathrm{BMI}<18.5 \\
(n=17)\end{array}$ & $\begin{array}{l}18.5 \leq B M I \leq 25 \\
(n=47)\end{array}$ & $\begin{array}{l}\text { BMI > 25 } \\
(n=17)\end{array}$ \\
\hline Serum IL-35 levels median (IQR), (pg/ml) & $11.6(5.1-16.8)$ & $1.5(0.8-3.2)$ & $<0.0001$ & $15.2(6.0-25.8)$ & $12.7(5.3-16.7)$ & $7.8(4.1-11.3)$ \\
\hline
\end{tabular}



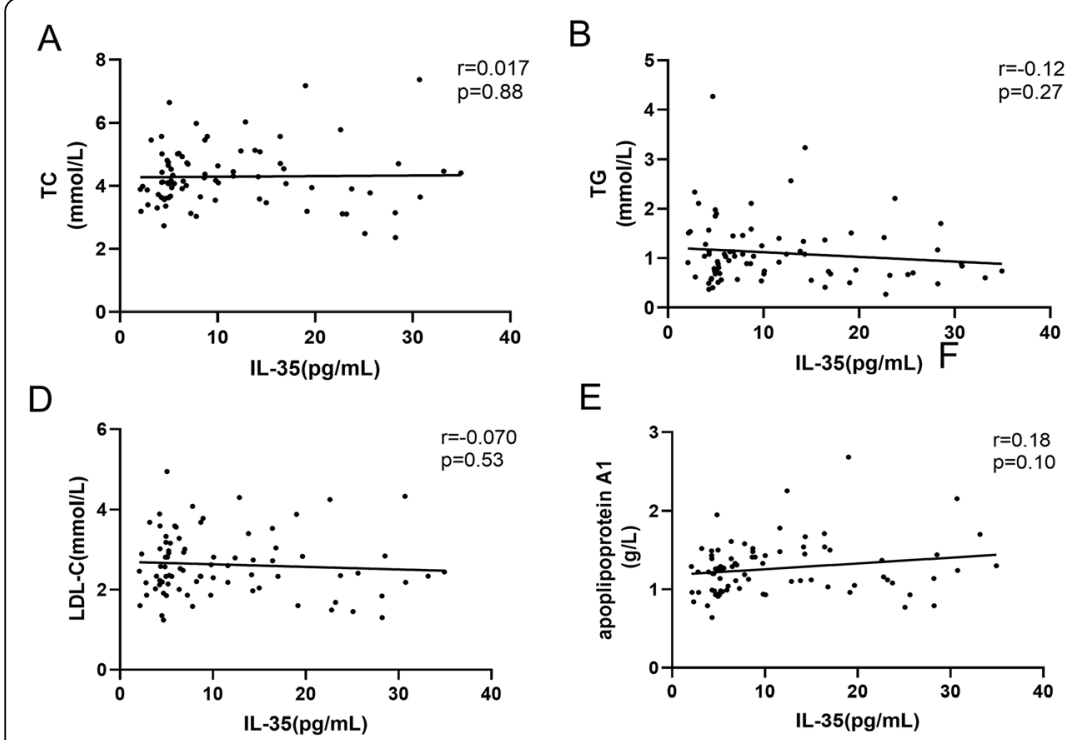

$\mathrm{E}$
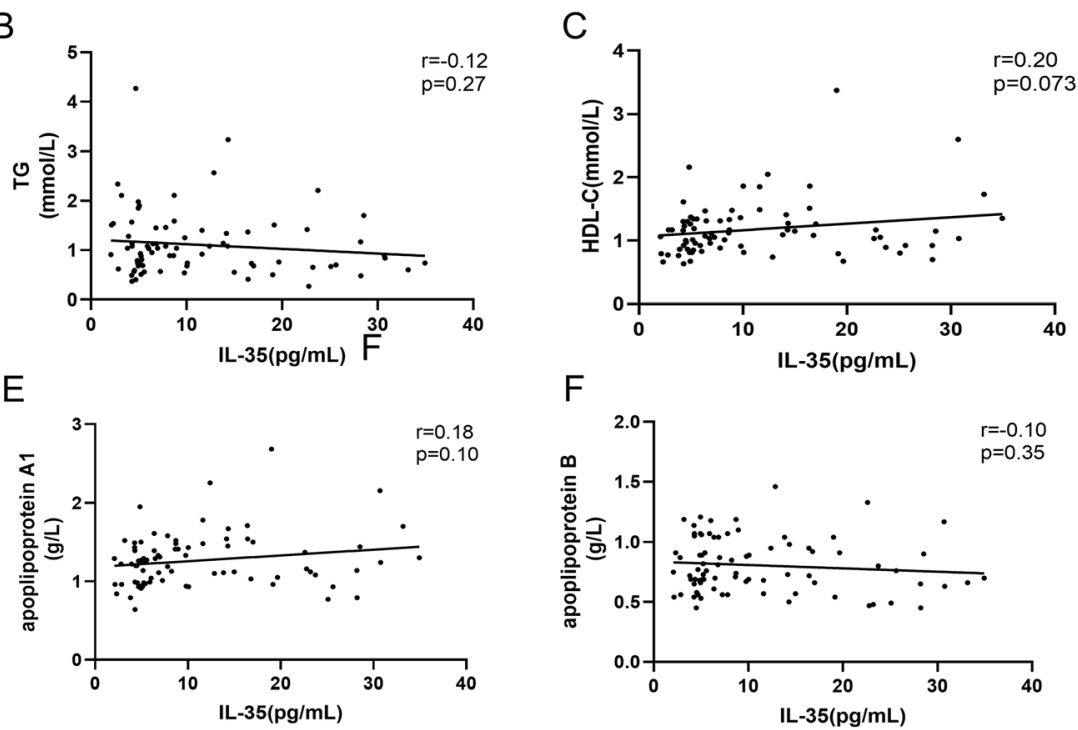

F

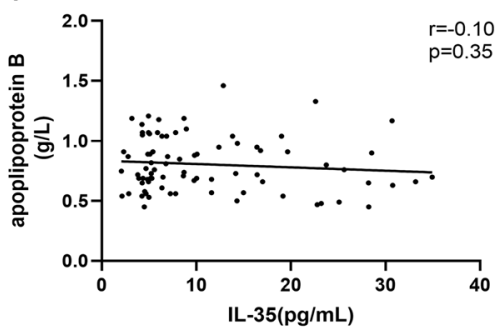

G

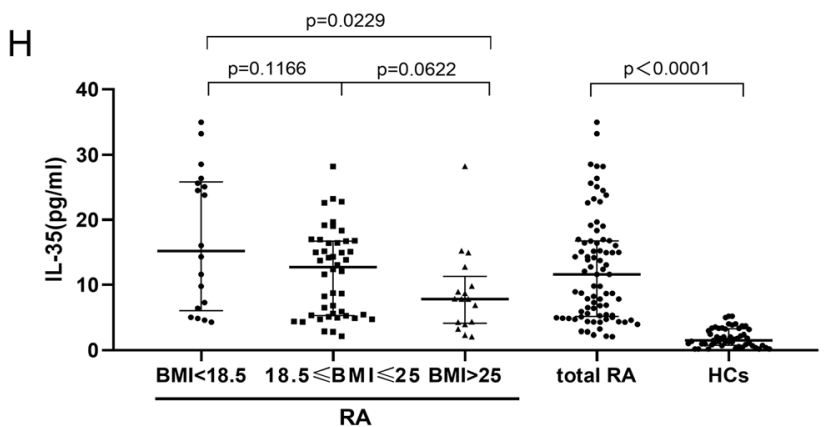

Fig. 1 (A, B, C, D, E, F) Correlation between serum IL-35 levels and lipid profile including TC, TG, HDL-C, LDL-C, apoplipoprotein A1 and apoplipoprotein B;(G) Correlation between serum IL-35 levels and BMI; $(\mathbf{H})$ Serum IL-35 levels in three groups categorized to BMI $(<18.5, \geq 18.5$ to $25,>25)$. Abbreviation: TC, total cholesterol; TG, triglyceride; HDL-C, high-density lipoprotein cholesterol; LDL-C, low-density lipoprotein cholesterol; IL, Interleukin; BMI, body mass index

and Tregs are observed. The results showed that serum level of IL-17 was found to be significantly higher in the overweight group with RA than in lean controls which coincided exactly with experimental results of Hirofumi

Table 3 Correlations between BMI and DAS28, Th1/Th2/Th17related cytokines in patients with RA

\begin{tabular}{lll}
\hline & Coefficient & $\mathbf{P}$ \\
\hline DAS28 & 0.2258 & 0.0427 \\
IL-2 & -0.1395 & 0.0835 \\
IL-4 & 0.1326 & 0.2381 \\
IL-6 & 0.2292 & 0.0067 \\
IL-10 & -0.0571 & 0.6126 \\
IL-17A & 0.4761 & $p<0.0001$ \\
IFN- $\boldsymbol{\gamma}$ & 0.0699 & 0.5353 \\
TNF- $\boldsymbol{a}$ & 0.4500 & $p<0.0001$ \\
\hline
\end{tabular}

Abbreviations: DAS28 disease activity score in 28 joints based on erythrocyte sedimentation rate; IL interleukin, $B M I$ body mass index, IFN interferon, TNF tumor necrosis factor
Shoda, et al, which demonstrating quantitative and qualitative changes in Th17 cells were characteristic in overweight patients with RA [24]. These alterations suggest a loss of $\mathrm{T}$ cell homeostasis, which may lead to local tissue and systemic inflammation and immunity in RA. Recent studies have confirmed that $\mathrm{T}$ cells are mediated in adipose tissues and may lead to obesity-induced inflammation [25]. Due to the anti-inflammatory role of IL-35 and its selective activities to proliferate regulatory $\mathrm{T}$ cells and suppress Th17 cells, it could postulate that the negative correlation between IL-35 and BMI due to the negative feedback immune response activated by pro-inflammatory molecules, which could inhibit excessive autoimmune response.

In order to analyze the potential regulators involved with the altered lymphocyte activation in overweight patients with RA, serum concentrations of Th1/Th2/Th17realted cytokines were measured. Obesity is characterized by a state of chronic low-grade inflammation called meta-inflammation in which the immune cells, especially monocytes, are induced, infiltrate the adipose tissue and 


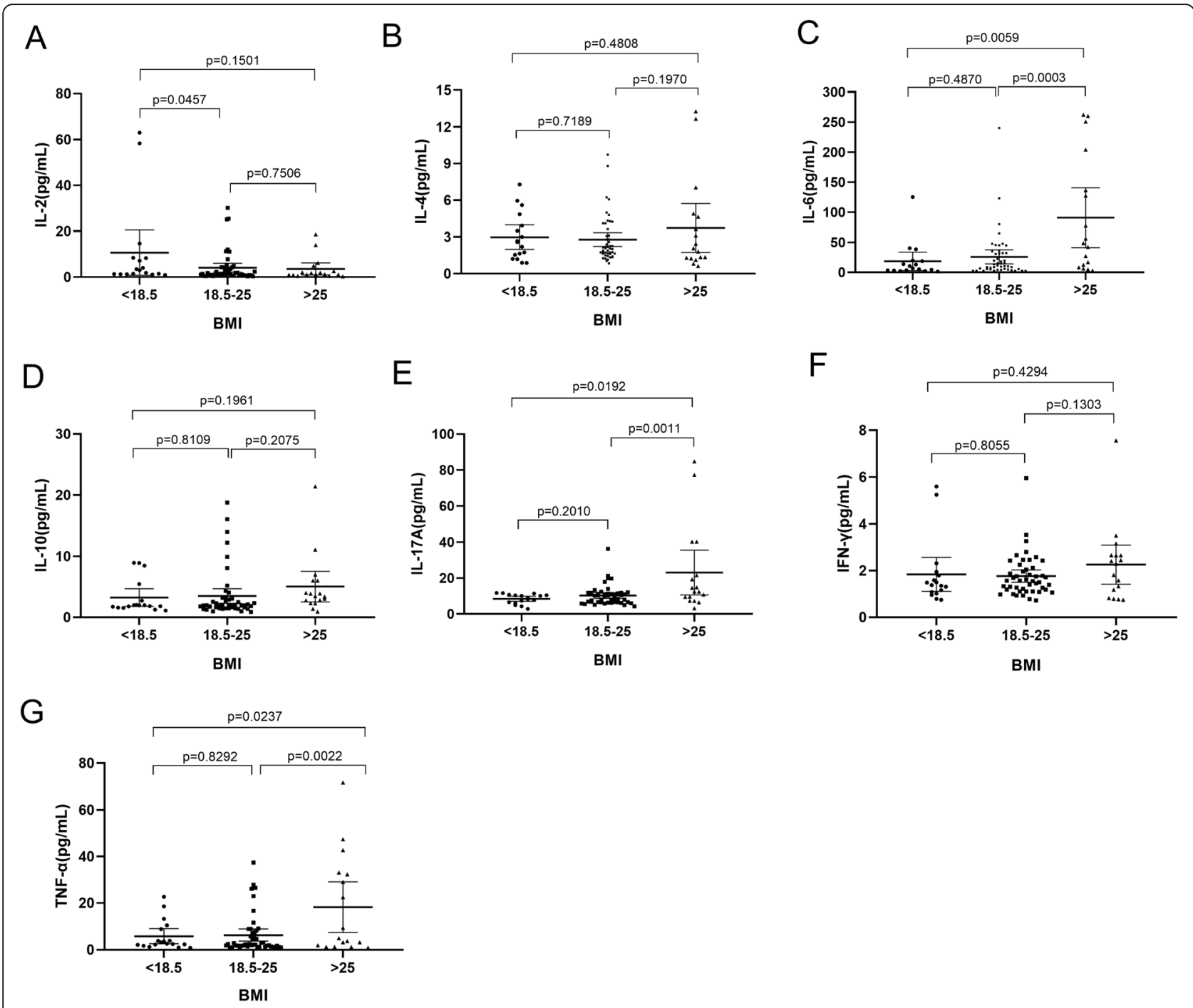

Fig. 2 (A, B, C, D, E, F, G) Serum cytokines levels of IL-2, IL-4, IL-6, IL-10, IL-17A, IFN- and TNF-ain in three groups categorized to BMI (< 18.5, $\geq 18.5$ to $25,>25)$. Abbreviation: IL: interleukin; BMI: body mass index; IFN: interferon; TNF: tumor necrosis factor

become differentiated as resident adipose tissue macrophages (ATMs). ATMs are classified by the expression of M1 or proinflammatory markers including IL-6 and TNF- $\alpha$ [26]. Therefore, it could be explicable that serum levels of IL- 6 and TNF- $\alpha$ are higher in obese patients with RA than those of lean patients with RA. Furthermore, changes in the IL-35 with changes in the IL-17 is rational which may be due to the suppressive role of IL35 which affect the proliferation and differentiation of Th17 as the producers of IL-17. Recent studies have demonstrated that obesity selectively stimulate the secretion of IL-17 producing CD4 + T (Th17) cells in adipose tissues, aggravating autoimmune response in mice model [27]. In obese collagen-induced arthritis mice model, which is a new animal model of RA, indicates the amplified inflammatory state, especially through Th17 deviation. The number of Th17 cells and IL-17 mRNA expression of the splenocytes were elevated in obese CIA mice compared with those of lean counterpart [28]. However, other non-significant relationships between BMI and serum concentrations of IL-2, IL-4, IL-10 and IFN- $\gamma$ could not be explained that obesity induce no changes in the expression of above cytokines, which might be related to the determination of above cytokines in the local joint tissue-not in the serum. For more confirmation, evaluation the serum level of IL-2, IL-4, IL-10 and IFN- $\gamma$ in synovial fluid and fibroblast-like synoviocytes in patients with RA and in healthy controls.

\section{Conclusions}

BMI was closely linked to chronic inflammation in patients with RA, and quantitative change of IL-35 were 
observed in overweight patients with RA. We speculated that the overweight patients with RA were a subgroup of patients with RA who had the unique immunological features. The role of IL-35 should be further investigated in RA, especially overweight patients in RA. A better understanding of the arthritis-obesity interaction will help us to improve a personalized management directed against both the disease and its associated comorbidities.

\section{Methods}

\section{Patients}

A total of 81 patients with RA and 53 healthy controls (HCs) at the First Affiliated Hospital of China Medical University and the Shengjing hospital of China Medical University were recruited for this study. The recruited patients all met the American Colleague of Rheumatology criteria for RA [29]. All patients did not receive any therapy with glucocorticoids and/or immunosuppressants. Body mass index $(<18.5, \geq 18.5$ to $25,>25)$ was classified as previously defined. Blood tests for erythrocyte sedimentation rate (ESR) and C-reactive protein (CRP) were measured by Westergren method, immune transmission turbidity method, respectively. Rheumatoid factor (RF) (cut-off value of $19 \mathrm{IU} / \mathrm{ml}$ ) and anti-cyclic citrullinated peptide antibodies (ACPA) (cut-off value of $20 \mathrm{U}$ ) were assessed by immunoturbidimetric assays and chemiluminescence analysis, respectively. Each patient's swollen joint count (SJC) and tender joint count (TJC) were assessed. Written informed consent was provided by all subjects, and the study was approved by the ethics committee of the First Affiliated Hospital of China Medical University and Shengjing Hospital of China Medical University and was conducted according to the Declaration of Helsinki.

\section{Detection of serum IL-35}

Blood samples were acquired from the recent-onset RA patients. Serum IL-35 levels were measured using Enzyme Linked Immunosorbent Assay (ELISA) kits (eBioscience, San Diego, CA, USA) according to the manufacturer's protocol. Briefly, Add $100 \mu \mathrm{L}$ of sample or standards in reagent diluent (1:1) per well. Cover with an adhesive strip and incubate $2 \mathrm{~h}$ at room temperature. Repeat the aspiration/wash as previous plate preparation. Add $100 \mu \mathrm{L}$ of the Detection Antibody, diluted in reagent diluent, to each well. Cover with a new adhesive strip and incubate $2 \mathrm{~h}$ at room temperature. Repeat the aspiration/wash as previous plate preparation. Add $100 \mu \mathrm{L}$ of the working dilution of Streptavidin-HRP to each well. Cover the plate and incubate for $20 \mathrm{~min}$ at room temperature. Avoid placing the plate in direct light. Repeat the aspiration/wash as previous plate preparation. Add $100 \mu \mathrm{L}$ of substrate solution to each well. Incubate for
$20 \mathrm{~min}$ at room temperature. Avoid placing the plate in direct light. Add $50 \mu \mathrm{L}$ of Stop Solution to each well. Gently tap the plate to ensure thorough mixing. The optical density was measured at $450 \mathrm{~nm}$ using an automatic ELISA reader.

\section{Determination of Th1/Th2/Th17-related cytokine levels}

Serum cytokines, which were representative of Th1/ Th2/Th17-related cytokines including IL-2, IL-4, IL-6, IL-10, IL-17A, INF- $\gamma$, TNF- $\alpha$ levels, were measured using Flowcytometry assay (BD ${ }^{\text {mix }}$ Cytometric Bead Array Human Th1/Th2/Th17 Cytokine Kit) according to the manufacturer's protocol. BD FACSVerse system were used for the detection and analysis of the serum levels of the cytokines IL-2, IL-4, IL-6, IL-10, IL-17A, IFN- $\gamma$, and TNF- $\alpha$.

\section{BMI and lipid profile assessment}

BMI was assessed as the weight in kilograms divided by height in meters squared. It was categorized into three groups according to the definition of the World Health Organization (WHO): underweight $\left(<18.5 \mathrm{~kg} / \mathrm{m}^{2}\right)$, normal weight $\left(18.5-<25 \mathrm{~kg} / \mathrm{m}^{2}\right)$, overweight and obese $(\geq 25$ $\mathrm{kg} / \mathrm{m}^{2}$ ).

Lipid profile included total cholesterol (TC), triglyceride (TG), low-density lipoprotein cholesterol (LDL-C), high-density lipoprotein cholesterol (HDL-C), apoplipoprotein A1, and apoplipoprotein B. All lipids were measured using the automatic biochemical analyzer (Abbott ARCHITECT ci16200, American) at our hospital's laboratory. The level of serum TC was measured using cholesterol oxidase method (Hitachi Chemical Diagnostics Systems, No 061039). The level of serum TG was measured using GB\&Enzyme method (Hitachi Chemical Diagnostics Systems, No 0610926). The level of serum LDL-C was measured using selective melt method (Hitachi Chemical Diagnostics Systems, No 061036). The level of serum HDL-C was measured using chemical modification enzyme method (Hitachi Chemical Diagnostics Systems, No 061077). And the levels of serum apoplipoprotein A1 and apoplipoprotein B were measured using turbidimetric inhibition immuno assay (Dia System, No, 50,244,100/26467, 50,244,140/26807).

\section{Statistical analysis}

All data are presented as mean \pm standard error (SE) or median (interquartile range (IQR)) if continuous and as counts and percent if categorical. Differences between groups were tested with one-way analysis of variance (ANOVA), followed by a Turkey's multiple comparisons post-test. $X^{2}, t$-tests and logistic regression models were used to compare the study groups and to explore the association between obesity and serum cytokines in RA. All analyses were performed using SPSS 17.0 (SPSS Inc., 
Chicago, IL), and GraphPad prism 7 software. Differences of $p<0.05$ were considered significant.

\section{Abbreviations}

RA: rheumatoid arthritis; BMI: body mass index; IL: interleukin; TNF: tumor necrosis factor; IFN: interferon; EBI3: Epstein-Barr virus-induced 3; Tregs: regulatory T cells; CIA: collagen-induced arthritis; HCs: healthy controls; CRP: C-reactive protein; ESR: erythrocyte sedimentation rate; RF: rheumatoid factor; ACPA: anti-cyclic citrullinated peptide antibodies; SJC: swollen joint count; TJC: tender joint count; VAS: visual analogue scale; DAS28-ESR: disease activity score in 28 joints based on erythrocyte sedimentation rate; IQR: interquartile range; SE: standard error; ELISA: Enzyme Linked Immunosorbent Assay; TC: total cholesterol; TG: triglyceride; LDL-C: lowdensity lipoprotein cholesterol; HDL-C: high-density lipoprotein cholesterol

\section{Supplementary Information}

The online version contains supplementary material available at https://doi. org/10.1186/s12865-021-00431-x.

Additional file 1: Supplementary Figure 1. $(\mathrm{A}-\mathrm{H})$ Correlation between BMI and DAS28, IL-2, IL-4, IL-6, lil-17A, IFN- $\gamma$ and TNF- $a$. Abbreviations: DAS28: disease activity score in 28 joints based on erythrocyte sedimentation rate; IL: interleukin; BMI: body mass index; IFN: interferon; TNF: tumor necrosis factor.

Additional file 2: Supplementary Figure 2. (A-D) The typical twodimensional scatter diagrams of the frequency of Th1/Th2/Th17-Related Cytokines in patients with RA.

\section{Acknowledgements}

None.

\section{Authors' contributions}

Conceptualization: $Y X$ L. Data curation: $Y X L$ and J Y. Formal analysis: $Y X L$ and J Y. Funding acquisition: $J L$ and $X F W$. Investigation: $Y X L$ and $J Y$. Methodology: YX L. Supervision: $J L$ and XF W. Writing-original draft: $Y X L$. Writing review\& editing: $J \mathrm{~L}$ and $X F \mathrm{~W}$. All authors have read and approved the manuscript.

\section{Funding}

This study was funded by China Postdoctoral Science Foundation (2019 M661173) and 345 Talent Project of Shengjing Hospital of China Medical University.

\section{Availability of data and materials}

The data used to support the findings of this study are available from the corresponding author upon request.

\section{Declarations}

\section{Ethics approval and consent to participate}

Written informed consent was provided by all subjects, and the study was approved by the ethics committee of the First Affiliated Hospital of China Medical University and Shengjing Hospital of China Medical University and was conducted according to the Declaration of Helsinki.

\section{Consent for publication}

Not Applicable.

\section{Competing interests}

Yuxuan Li, Jie Yang, Xiaofei Wang, Jing Lu declare that they have no conflicts of interest.

Received: 22 November 2020 Accepted: 14 June 2021

Published online: 27 June 2021

\section{References}

1. Klaasen R, Wijbrandts CA, Gerlag DM, Tak PP. Body mass index and clinical response to infliximab in rheumatoid arthritis. Arthritis Rheum. 2011:63(2): 359-64. https://doi.org/10.1002/art.30136.
2. Gremese E, Carletto A, Padovan M, Atzeni F, Raffeiner B, Giardina AR, et al. Obesity and reduction of the response rate to anti-tumor necrosis factor alpha in rheumatoid arthritis: an approach to a personalized medicine. Arthritis Care Res. 2013;65(1):94-100. https://doi.org/10.1002/acr.21768.

3. Sandberg ME, Bengtsson C, Källberg H, Wesley A, Klareskog L, Alfredsson L, et al. Overweight decreases the chance of achieving good response and low disease activity in early rheumatoid arthritis. Ann Rheum Dis. 2014; 73(11):2029-33. https://doi.org/10.1136/annrheumdis-2013-205094.

4. Ajeganova S, Andersson ML, Hafstrom I. Association of obesity with worse disease severity in rheumatoid arthritis as well as with comorbidities: a longterm followup from disease onset. Arthritis Care Res. 2013;65(1):78-87. https://doi.org/10.1002/acr.21710

5. Bluher M. Adipose tissue inflammation: a cause or consequence of obesityrelated insulin resistance? Clinical science (London, England : 1979). 2016; 130(18):1603-14

6. Fantuzzi G. Adiponectin in inflammatory and immune-mediated diseases. Cytokine. 2013;64(1):1-10. https://doi.org/10.1016/j.cyto.2013.06.317.

7. Fantuzzi G. Adipose tissue, adipokines, and inflammation. J Allergy Clin Immunol. 2005;115(5):911-9; quiz 920. https://doi.org/10.1016/j.jaci.2005.02.023.

8. Catalan-Dibene J, McIntyre LL, Zlotnik A. Interleukin 30 to Interleukin 40. J Interferon Cytokine Res. 2018;38(10):423-39. https://doi.org/10.1089/jir.2018. 0089 .

9. Collison LW, Vignali DA. Interleukin-35: odd one out or part of the family? Immunol Rev. 2008;226(1):248-62. https://doi.org/10.1111/j.1600-065X.2008. 00704.x.

10. Yokota M, Suzuki M, Nakamura Y, Ozaki S, Murakami S. Cytokine modulation by IL-35 in mice with allergic rhinitis. Am J Rhinol Allergy. 2015;29(4):251-6. https://doi.org/10.2500/ajra.2015.29.4188.

11. Bettini $M$, Castellaw $A H$, Lennon GP, Burton AR, Vignali DA. Prevention of autoimmune diabetes by ectopic pancreatic $\beta$-cell expression of interleukin35. Diabetes. 2012;61(6):1519-26. https://doi.org/10.2337/db11-0784.

12. Feldmann M, Brennan FM, Maini RN. Role of cytokines in rheumatoid arthritis. Annu Rev Immunol. 1996;14(1):397-440. https://doi.org/10.1146/a nnurev.immunol.14.1.397.

13. Mclnnes IB, Schett G. Cytokines in the pathogenesis of rheumatoid arthritis. Nat Rev Immunol. 2007:7(6):429-42. https://doi.org/10.1038/nri2094.

14. Burska A, Boissinot M, Ponchel F. Cytokines as biomarkers in rheumatoid arthritis. Mediat Inflamm. 2014:2014:545493.

15. Charlton B, Lafferty KJ. The Th1/Th2 balance in autoimmunity. Curr Opin Immunol. 1995;7(6):793-8. https://doi.org/10.1016/0952-7915(95)80050-6.

16. Aarvak T, Chabaud M, Thoen J, Miossec P, Natvig JB. Changes in the Th1 or Th2 cytokine dominance in the synovium of rheumatoid arthritis (RA): a kinetic study of the Th subsets in one unusual RA patient. Rheumatology (Oxford). 2000;39(5):513-22. https://doi.org/10.1093/rheumatology/39.5.513.

17. Shoelson SE, Herrero L, Naaz A. Obesity, inflammation, and insulin resistance. Gastroenterology. 2007;132(6):2169-80. https://doi.org/10.1053/j. gastro.2007.03.059.

18. Finckh A, Turesson C. The impact of obesity on the development and progression of rheumatoid arthritis. Ann Rheum Dis. 2014;73(11):1911-3. https://doi.org/10.1136/annrheumdis-2014-205741.

19. Ning $X$, Jian $Z$, Wang W. Low serum levels of interleukin 35 in patients with rheumatoid arthritis. Tohoku J Exp Med. 2015;237(2):77-82. https://doi.org/1 0.1620/tjem.237.77.

20. Collison LW, Chaturvedi V, Henderson AL, Giacomin PR, Guy C, Bankoti J, et al. IL-35-mediated induction of a potent regulatory T cell population. Nat Immunol. 2010;11(12):1093-101. https://doi.org/10.1038/ni.1952.

21. Niedbala W, Wei XQ Cai B, Hueber AJ, Leung BP, Mclnnes IB, et al. IL-35 is a novel cytokine with therapeutic effects against collagen-induced arthritis through the expansion of regulatory T cells and suppression of Th17 cells. Eur J Immunol. 2007;37(11):3021-9. https://doi.org/10.1002/eji.200737810.

22. Li Y, Yao L, Liu S, Wu J, Xia L, Shen H, et al. Elevated serum IL-35 levels in rheumatoid arthritis are associated with disease activity. J Investigative Med. 2019;67(3):707-10. https://doi.org/10.1136/jim-2018-000814.

23. Li Y, Yuan L, Yang J, Lei Y, Zhang H, Xia L, et al. Changes in serum cytokines may predict therapeutic efficacy of Tofacitinib in rheumatoid arthritis. Mediat Inflamm. 2019:2019:5617431.

24. Shoda H, Nagafuchi Y, Tsuchida Y, Sakurai K, Sumitomo S, Fujio K, et al. Increased serum concentrations of IL-1 beta, IL-21 and Th17 cells in overweight patients with rheumatoid arthritis. Arthritis Res Therapy. 2017; 19(1):111. https://doi.org/10.1186/s13075-017-1308-y. 
25. Feuerer M, Herrero L, Cipolletta D, Naaz A, Wong J, Nayer A, et al. Lean, but not obese, fat is enriched for a unique population of regulatory $T$ cells that affect metabolic parameters. Nat Med. 2009;15(8):930-9. https://doi.org/10.1 038/nm.2002

26. Sindhu S, Thomas R, Shihab P, Sriraman D, Behbehani K, Ahmad R. Obesity is a positive modulator of IL-6R and IL-6 expression in the subcutaneous adipose tissue: significance for metabolic inflammation. PLoS One. 2015; 10(7):e0133494. https://doi.org/10.1371/journal.pone.0133494.

27. Winer S, Paltser G, Chan Y, Tsui H, Engleman E, Winer D, et al. Obesity predisposes to Th17 bias. Eur J Immunol. 2009;39(9):2629-35. https://doi. org/10.1002/eji.200838893.

28. Jhun JY, Yoon BY, Park MK, Oh HJ, Byun JK, Lee SY, et al. Obesity aggravates the joint inflammation in a collagen-induced arthritis model through deviation to Th17 differentiation. Exp Mol Med. 2012;44(7):424-31. https:// doi.org/10.3858/emm.2012.44.7.047.

29. Aletaha D, Neogi T, Silman AJ, Funovits J, Felson DT, Bingham CO 3rd, et al. Rheumatoid arthritis classification criteria: an American College of

Rheumatology/European league against rheumatism collaborative initiative. Arthritis Rheum. 2010;62(9):2569-81.

\section{Publisher's Note}

Springer Nature remains neutral with regard to jurisdictional claims in published maps and institutional affiliations.

Ready to submit your research? Choose BMC and benefit from:

- fast, convenient online submission

- thorough peer review by experienced researchers in your field

- rapid publication on acceptance

- support for research data, including large and complex data types

- gold Open Access which fosters wider collaboration and increased citations

- maximum visibility for your research: over $100 \mathrm{M}$ website views per year

At $\mathrm{BMC}$, research is always in progress.

Learn more biomedcentral.com/submissions 